\title{
Exploring the Role of Supplier Relationship \\ Management for Sustainable Operations: An OR \\ Perspective
}

\author{
Amir M. Sharif ${ }^{1}$ \\ Sarmad Alshawi \\ Muhammad M. Kamal \\ Tillal Eldabi and \\ Aiyaz Mazhar \\ Brunel Business School \\ Brunel University \\ Uxbridge, Middlesex, UB8 3PH \\ ${ }^{1}$ Corresponding Author
}

\begin{abstract}
This paper provides a systems-based approach to the exploration of the relationship and integration between Supplier Relationship Management (SRM) factors as part of a Sustainable Operations Management (SOM) agenda. The authors have chosen electronic procurement (e-Procurement) as a suitable context in this light. Through a review of extant literature, a Systems Archetype (SA) model is developed (based upon the "Accidental Adversaries" archetype) and findings from a quantitative pilot study exploring key factors pertinent to e-Procurement SRM were gathered, and hence evaluated against SOM factors.. The objective of this research was to describe and visualise the causal inter-relationships involved in SRM-SOM through the application of systems archetype (as an OR tool). The also authors believe that this research also provides a unique approach to developing and harnessing the useful and unique properties of Systems Thinking (ST), by attempting to reduce and organise the (generally adhoc and wide-ranging) sequence of subjective perspectives commonly experienced in causal mapping experiments. The paper builds upon the extant literature, and provides further basis for continuing research in the areas of Systems Thinking, Systems Archetypes and the application of operational research to plan sustainable operations .
\end{abstract}

Keywords: Sustainable Operations Management, Supplier Relationship Management, Systems Archetype 


\section{Introduction}

The procurement of goods and services is an important function of any organisation which in turn can have a direct impact on the profitability of an organisation. The automation of this function through electronic procurement (e-Procurement), continues to be a growth industry in itself accounting for well over $\$ 3$ trillion in annual transactions (Verespej, 2002). Much of this growth can be attributed to the manner by which Internet and associated technologies have helped to change the role of procurement departments from transaction-oriented functions, to transformation-oriented and hence strategic functions. So-called "strategic procurement and sourcing" therefore relies not only on the procurement activity itself but also focusses on developing and maintaining relationships with suppliers and additional corporate buying relationships, via Supplier Relationship Management (SRM) (Gebauer et al., 1998). Kenneth and Farrington (2012) indicate that e-Procurement plays an important role in the sustainability of streamlining and optimising the whole supply chain - of which SRM is an inherent part. SRM has in itself likewise been supported through a growing number of communication channels that have made the relationship management activity more versatile between buyer and supplier. Many e-Procurement ICT-based applications and platforms now exist which affect the relationship with suppliers in different ways - these include private networks, electronic catalogues and electronic marketplaces (Wagner and Essig, 2006). On a transactional level, immediate operational benefits are visible which relate to more efficient and effective purchasing (Gunasekaran et al., 2009). At the transformational level, e-Procurement approaches have also been identified to provide additional benefits which include better information sharing between buyer and suppliers, improved relationship with suppliers (Gunasekaran et al., 2009), the ability to explore and build relationship with new suppliers (Attaran, 2001).

At the same time it has long been recognised that face-to-face communication lies at the heart of any business-to-business relationship (Carr and Kaynak, 2007).. Even given the above increase in the use of e-Procurement technologies to support SRM, Wognum et al., (2002) suggest that advanced communication technologies cannot fully replace face-to-face communication and the trust that is inherent in many buyer-supplier relationships; rather, ICTs provide additional opportunities to share information, as noted also by Luscombe (2010) and Winger (2005) - although Nguyen and Nguyen (2011) note that personal interactions between buyers and suppliers still have a positive and lasting effect on SRM value. 
Whilst there has been a propensity for research to focus on mature and developed markets in relation to traditional, as well as electronic, procurement there is a paucity of research in relation to understanding the impact of e-Procurement and SRM in developing countries (beyond for example the study in the UAE by Aboelmaged, 2010). Additionally, in the emergent topical area of Sustainable Operations Management (SOM) where alternative methods are being sought within an ever efficient and effective (and so-called low carbon and environmentally conscious) envelope - there is hence also little research in the SRM factors involved, especially around e-Procurement.

Given that such a context involves an interacting set of stakeholders, the authors have identified a potential for research into e-Procurement as part of the buyer-supplier SRM process, based upon examining input and output flows between each constituent stakeholder within the Pakistani e-Procurement context. In order to examine this further, the authors have taken their inspiration from the field of Soft Operations Research (OR) as well as the well-known and well-respected approach of System Dynamics (SD). Both of these techniques are particularly well-suited to not only modelling but exploring human-based relationships, causes and interactions (Forrester, 1961; Forrester, 1994; Sterman, 2000). The authors have used this as the starting context for examining the SRM-SOM relationship. However, although this is a useful starting point the authors wish to utilise additional concepts to explore the above points further.

The conceptual approach of Systems Thinking (ST) and associated approaches has been described in detail by Atkinson and Checkland (1988), Checkland (1981), Checkland and Scholes (1997) and Senge et al. (1994) and as such will not be presented in further detail here. Suffice to say that the development and application of ST was a direct result of the failure of systems engineering approaches to cope with poorly-structured management problems. As a technique, ST broadly seeks to represent and analyse the feedback behaviour in in systems which exhibit growth or stability over time. Thus in contrasting ST with Soft OR, the authors agree with the definition provided by Lane (1993) who notes that the former is involved with defining models of behaviour whilst the latter focusses on the dynamics of the model to simulate the representation of the system.

In extending their thinking around investigating SRM-SOM in terms of the e-Procurement context, the authors believe that dynamic "patterns", known as Systems Archetypes (SA), may instead be a more useful and appropriate means to explore the SRM-SOM interaction (Senge et al., 1994). Ultimately an archetype describes a form of behaviour within an interacting system through a range of feedback loops, and is generally used to describe and 
explore a range of social, organisational, political or economic situations. Each of the archetypes describes situations where there may be interplay between the consumption and sharing of resources, the improvement of performance, competition and negotiation, positive or negative feedback loops and / or selection of strategic choices.

Thus in the context of this paper, the authors are solely interested in the ethos of the relevant parts of the above approaches to conceptually model and structure the SRM-SOM relationship (in the vein but not the manner of Mingers and Rosenhead, 2004 and Checkland, 1981), using the SA approach. This research is not seeking to simulate a system or its components in the quest for an optimal solution as might be the case through other hard OR approaches per se, but to represent and visualise the internal interactions of the system through an archetype representation. The application of an SA in this regard is chosen by the authors to explain and then explore the SRM-SOM relationship within the overall context of e-Procurement.

The authors report on findings from a pilot study survey into e-Procurement use in Pakistan, where a quantitative instrument has been used to gather pertinent SRM factors. The results of this analysis have then been used a-posteriori to update and inform the definition of an SRM-SOM pattern, based upon the "Accidental Adversaries" archetype. In doing so, seeking to describe and visualise the dynamic as well as causal inter-relationships involved between SRM-SOM actors (buyer-supplier) in this context in a qualitative manner. The authors have used a mixed approach to bring both quantitative and qualitative perspectives on the problem domain together. The research design in this regard is unique as normally when an SA approach is applied, there is a strong subjective and heuristic perspective - but in this research, the authors utilise an empirical instrument to evaluate the development of this systems view of SRM-SOM. Ultimately this paper therefore aims to establish a link between SOM and SRM within the context of an in-transition market environment in order to identify the factors that lead to sustainable supplier relationship operations.

The paper is hence structured as follows. Section 2 presents the literature on the key factors of SOM. Section 3 presents the key factors of SRM, after which relevant cross-topic factors are identified between SOM and SRM. Section 4 proposes a three-step methodology design for developing the SA for SRM-SOM relationship. Factors identified in Section 3 are then used to develop the theoretical SA in Section 5 and hence section 5.1. Results from an SRM survey instrument which utilise elements of the cross-topic factors are then analysed in Section 5.2 in order to update and deepen the granularity of the SA. Section 5.3 presents the updated and final SA representing the SRM-SOM relationship from an e-Procurement 
perspective. Section 6 discusses the outcomes and how findings can be used. Section 7 presents conclusions and lessons learned from contextual and theoretical points of view.

\section{Sustainable Operations Management (SOM)}

The literature defines operations management as "the design, operation, and improvement of the systems that create and deliver the firm's primary products and services" (Chase et al., 2006, p. 9). It can be deduced from this definition that the concept of sustainable operations management projects the principle of carrying out efficient and successful operations management whilst also focusing on the organisation's impact on the environment. In the latter scenario, all core aspects of an organisation's systems including operations, procurement, and delivery are all influenced by the requisite need to safeguard and protect the environment (Kleindorfer et al., 2005). The latter argument has is also supported by Corbet (2009), who reports that the existing concern for the environment and increased awareness of global warming means the sustainable management of organisational resources and systems is becoming increasingly important. Sustainable operations management assimilates the turnover and efficiency orientation of conventional operations management with broader deliberations of the organisation's internal and external stakeholders and its environmental impact (Bettley and Burnley, 2008; Kleindorfer et al., 2005).

As several sustainability effects are firmly influenced by operations management decisions it is also essential that the operations management function incorporates the needs of sustainability management. SOM is not merely about supply-chain and the approach to introducing unprocessed material through finishing point and final delivery; however, it also requires organisations to focus on the wider issues of design and development, by-product and waste disposal and internal resource efficiencies to meet these aims. Typical approaches involve conducting a comprehensive lifecycle analysis to ensure that sustainability efforts are proactively decreasing the impact of operations upon the environment (i.e. reduction of carbon footprint). Thus, sustainable practices must be developed not just throughout a business, but specifically targeted to the operations throughout wherever possible.

SOM therefore also requires a cross-stakeholder and cross-business perspective to occur balancing the inputs and outputs of socio-economic systems, illustrating that sustainable operations management discipline thus needs to prove itself as multidisciplinary. Although, Kleindorfer et al., (2005) argues that the transition towards sustainable operations 
management is due to green product and process development, lean and green operations management and remanufacturing and closed-loop supply chains, there are other core variables that influence sustainable operations management. As such these are detailed and categorized further in Table 1.

\section{Insert Table 1 here}

\section{Supplier Relationship Management (SRM)}

Organisations have optimised their product supply chain to bring together buyers and suppliers to yield enormous efficiencies (Eulálio et al., 2007). However, in order for supply chain management to perform successfully, the purchasing function must be properly considered, where the significance of the purchasing function increases as the purchasing and outsourcing costs assume a greater portion of the total costs of the manufacturing process as Park et al., (2010) argue. In response to this, organisations have showed interest in developing and sustaining their supplier relationship management systems and working relationships (Monczka et al., 2000). In order to make supplier chains more agile and leaner however, organisations have been keen to give more importance to tiers further up the supply chain, and in this context, relationships between suppliers and buyers are still considered to be a strategic part of the supply chain (Meier et al., 1998). Hence authors such as Wagner (2000), refer to SRM as the design and development of a company's supplier portfolio and the relationships the company has with its suppliers whilst Poirier (2010) denotes SRM as a process that provides ways of how a business should interact with its different suppliers with the aim of working together for mutual benefits.

Whichever definition is used, a key feature that is consistent is that SRM provides a method for facilitating a buyer's collaboration with a supplier - and vice versa (Carter, 2003), whilst seeking to manage an organisation's interactions with those external organisations that supply the goods and services it uses (Park et al., 2010). Thus, the purpose of SRM is to streamline and make the process between an organisation and its suppliers more effective (the corollary for customers, customer relationship management, is similar in that it anticipates to streamline and make company-customer relationship smoother, Choy et al., 2004). The latter argument is supported by Moeller et al., (2008, p. 73), who by differentiating between customer relationship management and supplier relationship management, state that: "supplier relationship management is the process of engaging in activities of setting up, developing, stabilising and dissolving relationships with in-suppliers as well as the observation of out-suppliers to create and enhance value within relationships". SRM therefore incorporates both business practices and software and is part of the information flow component of supply chain management (Park et al., 2010) and as a result, 
augments the efficiency of processes related to acquiring products and services, managing inventory, and processing materials (Day et al., 2008). In this manner, the authors believe that the best auspices of SRM are inherently in line with the aims of SOM (namely, efficiency, effectiveness, concern for the intra-organisational relationship within the wider environment). Extending this further, it is also pertinent to In order to further understand the two key types of SRM:

- Arms-Length Relationship: Arms-length SRM relationships are based upon transactions which are short term and typically focussed on price. Firms that adopt this approach, often switch between the suppliers in search of better price and relationship (Carter, 2003) and where low transaction frequency and low transaction uncertainty prevails.

- Partnership Relationship: A partnership SRM is one where a relationship develops over a period of time and requires more trust and information sharing between a buyer and a supplier. This relationship is useful in high uncertainty situations where transaction frequency is high (Kwon and Suh, 2004). Dyer et al. (1998) also argue that in such a relationship organisations should strive to develop partnerships with suppliers with whom they need to procure strategic inputs and, that contain a high proportion of customer-specific properties and serve to differentiate the end product.

Once more, SRM requires a uniformity of approach in order to nurture successful and productive working relationships that may then begin to involve shared processes and policies. Some of the more pertinent variables involved in SRM are presented from the literature in Table 2 and are further detailed in the subsections that follow.

\section{Insert Table 2 here}

Considering the procurement - and henceforth e-Procurement - perspective to the SRM context the authors now wish to add additional and pertinent factors to the above.

\subsection{Face-to-Face Interaction/Communication}

Face-to-face communication is considered the most effective way of communication between buyer and supplier, and is essential for successful and effective collaboration and provides a clear method to help build trust amongst one or several parties (Monczka et al., 1995). In addition since human relationships plays an important role in establishing business relationships, better relationships between buyers and suppliers can help both parties through better communication and understanding each other's goals (Pinnington and 
Scanlon (2009)). With the advent of Information and Communication Technologies (ICTs) however, Luscombe (2010) argues that eventually such communications mediums becomes less effective at the expense of becoming more efficient, such as in the case of e-mail (where there are fewer cues like eye contact and posture for people to rely on).

In a study conducted by Ambrose et al., (2008), some of the companies involved indicated that even though most of the transactions can be accomplished via the internet, they did not move away from face to face communication, and met regularly with their suppliers. Winger (2005) argues that the main reason face-to-face communication remains vital is that of productivity.

\section{2 e-Procurement Technologies}

Procurement can be defined as "process of acquiring goods, works and services, covering both acquisitions from thirds parties and from in-house providers" (Murray, 2009). Procurement encompasses all activities involved in obtaining goods and services and managing their inflow into an organisation (Jalal et al., 2009). Tatsis et al., (2006) define eProcurement as the integration, management, automation, optimisation and enablement of an organisation's procurement process, using electronic tools and technologies, and webbased applications. Adoption of e-Procurement technologies by companies is effected by a varied set of factors such as kind of technology, the firm itself, its trading partner or its business networks. (Iskandar et al., 2001; Osmonbekov et al., 2002; Davila et al., 2003; Bakker et al., 2008). A large number of e-Procurement technologies are available from simple email and fax to high end EDI networks (Wagner and Essig, 2006). However, this work mainly focuses on the major e-Procurement technologies that are currently in widespread use: Rai et al., (2006) have also presented four groups of electronic procurement innovations based on the major procurement processes (and as defined principally by Lysons and Farrington, 2006 and Wagner and Essig, 2006): electronic (forward and reverse)auctions, electronic catalogues (e-Catalogues), electronic order fulfilment and electronic payment and settlement, electronic marketplaces (e-Marketplaces) and electronic data interchange (EDI).

Hence noting all of the above technologies as well as mechanisms for improving the buyersupplier (and hence SRM) relationship, Table 3 details a mapping between the SOM and SRM factors derived from Table 1 and 2, in the context of e-Procurement. As can be seen, there are four common themes which are identified, which have their roots in the SOM literature but which resonate with SRM and hence e-Procurement aspects from Economic Sustainability through to Lean and Green Operations Management. These factors will be 
used later in order to develop the systems archetype linking the two areas together (which is why each SOM sub-variable is given a 3 or 4 letter abbreviations - ES, EVS, SS, LGOM).

\section{Insert Table 3 here}

\section{SRM-SOM SA development Methodology}

Noting the purpose and aims of this research in attempting to explore the inter-relationships between SOM and SRM within the e-Procurement context using a combined systems archetype (SA) and quantitative survey instrument, the authors now detail the research rationale and methodology.

As already noted and discussed, it is assumed that the buyer-supplier, hence SRM, context involves a quotient of human as well as technology-assisted communication and relationship transaction. Given the drive and impetus within the notion of SOM to enable business operations to be more efficient and effective with regards to green and other types of strategy as well, the authors wish to use the concept of SA to explore the interplay and relationship between SOM and SRM. In doing so, the authors believe that e-Procurement is a vital component in modern day SRM, and thus when also considering the notions of low carbon and associated operations which seek to limit the impact and effect on the environment, further granularity and understanding of the interplay between these factors is required. The SA development methodology is based on three steps: (1) developing a contextual-theoretic SA based on the literation; (2) collection of empirical data to evaluate the theoretical SA; and (3) updating the theoretical model based on the empirical data. This is to enable the theoretically developed archetype to be grounded empirically and hence as a result of reflective analysis, to be updated a-posteriori. The remainder of this section will provide a brief description of the rationale behind each of the three steps. The following sections will provide detailed discussion on the implementation of the methodology and refer to Figure 1

\section{Insert Figure 1 here}

STEP 1: the authors selected, developed and built an SA to describe the interactions involved in SRM - and hence SOM - based on the literature (i.e. the "Systems Archetype" rectangle in Figure 1). Archetypes are, as noted, graphical representations of social or organisational interactions which are based upon the concept of stocks and flows. This SA 
sought to describe the general case of the buyer-supplier relationship, noting any pertinent or other driving factors as appropriate.

STEP 2: in order to empirically evaluate the SA, the authors detailed the results of a quantitative survey on factors impacting SRM and the supplier-buyer divide (within the Pakistani e-Procurement context). Key correlations were then identified and ranked. Pairwise analysis was used to align these correlates with fundamental SRM and SOM factors identified in Step 1 (i.e. the "Data" rectangle in Figure 1).

STEP 3: the SA diagram was updated noting the respective inter-relationships identified and found as a result of the survey analysis (i.e. the second "Systems Archetype" rectangle in Figure 1). This step provided a picture of the relationships between SOM and SRM in the context of e-Procurement.

The primary empirical data was collected through the use of self-administered questionnaires (survey) in terms of a pilot study to investigate the SOM-SRM relationship in the e-Procurement case across organisations which included those in manufacturing, production, wholesale/retail, transportation and financial services organisations in Pakistan.

A purposive sampling technique was used to choose respondents relevant to the research (Saunders et al., 2009). The employees included senior managers, managers, assistant managers and other employees working in the procurement departments. The selfadministered questionnaire was used to gather information from the employees. 50 questionnaires were sent to different procurement professionals and 37 questionnaires were returned (i.e. a $74 \%$ response rate).

The survey was administered to a small population of procurement professionals $(n=31)$. Of these, role titles included Supply Chain Manager - as suppliers (15\% of the sample), Procurement Manager - as buyers ( $10 \%$ of the sample) or other Operations Manager $(8.2 \%$ of sample). The majority of the respondents were male (83.9\%) between the ages of 36 to 40 years old (51.6\%), $45.2 \%$ of the respondents having experience of procurement on the buy or sell side (or both) of more than five years but with a median experience of at least 1020 years in their own organisation. Characteristically, procurement teams in this context were identified as being quite small, with $58.1 \%$ of the sample having a team size of between three to four employees who were responsible for all their procurement activities. Key technologies used by these organizations largely focussed on the use of email, fax and videoconferencing for communication with their suppliers (i.e. 83.87\%). The population 
sample also highlighted that the responsibility for SRM lay with their supply chain managers (48.4\%). It was also observed that the companies in the sample population were are not fully aware of online SRM platforms such as e-Catalogues and e-Auctions, but at least $16.13 \%$ of them were already using EDI technology for their SRM processes.

The survey approach was deemed appropriate as the researchers were not attempting to create theory (which is inductive), but to add to theory via the positivist quantitative approach. The approach helped to identify potential inter-relationships between factors which in turn was used to develop the systems archetype models.

Validity of the survey instrument questions was maintained as most of the questions were obtained from previous studies such as Wagner and Essig (2006) and Gunasekaran et al., (2009). A purposive sampling technique was used to choose respondents from a range of suppliers and buyers, where the respondent demographic was targeted at the level of managers and directors of supply chain, operations and / or logistics in their company's procurement department (or equivalent).

\section{Implementation of the methodology: System Archetypes for supporting SRM Sustainability}

This section now details each of the Steps as defined in section 4 in further detail.

\subsection{Theoretical SRM-SOM SA}

As already mentioned and summarised in the introduction, SA are essential to conceptualising systems' structures and their patterns of behaviour over time in a graphical manner (Wolstenholme, 2003). Capturing behaviour over time is a very important feature for foreseeing unintended outcomes - and where supply or operations management is concerned this can be of vital importance. This is particularly true for complex and dynamic systems. Supply chains being an example of such systems.

Hence as mentioned previously also, the authors were interested in applying the SA concept as the basis for developing a conceptual framework describing the SOM- SRM field, noting the usefulness of such a systems approach in order to model a business context (Sharif, 2005). In addition, the authors seek to apply such an OR approach in the vein of Bell and Morse (2007) who note the appropriateness of using soft OR / problem structuring methods to handle the deconstruction of sustainable projects. There are a number of standardised system archetypes that are well documented in the literature, of which there are a principal number of ten in total (Braun, 2002). Each archetype represents a certain set of intended and unintended outcomes. The choice of any archetype to represent any given system is 
driven by the goal of the system and available resources. For example, whether a company is aiming to improve production given a tight deadline or expand their market presence. For this particular article our goal is represent and explore the relationships between SOM and SRM using an SA, evaluated by empirical data. In essence, there are a number of archetypes that deal with internal and external relationships. However, the authors felt that the most appropriate archetype to representing relationship sustainability is the one termed "Accidental Adversaries". This is because this archetype is the only one of the relational archetypes that deals with mutual sustainability rather than competing for resources (Wolstenholme, 2004). In the context of sustainable operations identified at the beginning of this paper, this fits well..

The basic concept of the accidental adversaries archetype is that it describes how partners may be faced with making decisions towards their own profitability versus decisions that would also lead to the success of other partners. Balancing the trust between business partners is one fundamental feature that is captured by this archetype, in a way that is not possible by any other OR method. In doing so, adopting this stance and taking this approach benefits not only the operations management field, but expands the use of archetypes as well. The accidental adversaries archetype is therefore capable of showing how some actions, however altruistic in nature, could accidentally lead to the demise of other partners. And that how sometimes misinterpretation or measures set against partners' actions could lead to further rifts and hence further demise to the relationship. The overall SA representation can be quite complex, and as such the authors now provide a factor-by-factor explanation of the parts of the SA (accidental adversaries) using the archetype examples as defined in Braun (2009).

The key elements of the "Accidental Adversaries" SA (Braun, 2000) is shown in Figure 2. The core elements of an adversarial type of relationship between two parties now start to emerge. This shows the combined Buyer and Supplier archetype loops and details that a buyers' success in purchasing (denoted by the positive causal sign, + ) can have a detrimental affect on the buyer's purchasing strategy (denoted by the negative causal sign, ). This is based upon the notion that if a purchasing approach is maintained without change, the impetus and strategy to purchase can become outdated and ineffective.

\section{Insert Figure 2 here}

The causal loop in terms of the perspective of the Supplier is a mirror image of the Buyer case, where once again the positive and negative causal loops identify the assumptions that 
if the Supplier's selling approach do not change, the sales strategies will by extension also not change, leading to a potentially negative impact upon the very same selling strategy.

However, noting the fact that an SA needs to explain and explore the behaviour of stakeholders, an unintended consequence of a change to buyer purchasing strategy might be to limit the supplier's margin and / or competitiveness - which would be in favour of the Buyer (the loop denoted with a + from "Buyer's purchasing strategies").

But in real terms this would have an impact on the supplier (i.e. the input going to "Supplier's selling strategies). The similar case is also valid between the Supplier and Buyer, where the supplier would seek to limit the Buyer's purchasing power (by say, for example, reducing inventory but raising sales costs). Hence Figure 4 shows the propensity for only two stakeholders in the e-Procurement context to be pitted against each other, where intended or unintended behaviours may have a detrimental effect on each other (hence accidental adversaries).

The outer balancing loop is a causal linkage between both of the "adversaries" is included because of the nature of the unintended and hence "accidental" consequences- and hence provides a possible intended consequence to partner with the other stakeholder for mutual benefit. Indeed, it is this principle upon which existing notions of SRM are largely based. Whilst it may be possible to conclude that this SA is a description / definition of a dyadic SRM situation, what is missing in the context of this research is the linkage to those sustainable operations (hence SOM) factors that may be influencing or interacting with either Buyer or Supplier.

Figure 3 therefore shows where each set of contributory factors from Table 3 is best aligned. These factors hence become inputs to the SA - and hence this visual relationship becomes conceptual as further relationships are not known.

\section{Insert Figure 3 here}

\subsection{Empirical Data to Evaluate the SRM-SOM SA}

As noted in the research methodology section that whilst an SA approach has been used to conceptualise the stakeholder relationships between Buyers and Suppliers up until this point, the authors aim was to try to provide an empirical basis for rationalising and ensuring such a systems-based model was not entirely subjective in nature. For this purpose a survey (selfadministered questionnaires) was conducted across organisations which included those in 
manufacturing, production, wholesale/retail, transportation and financial services in Pakistan. The survey consisted of two parts. The first part provided the general demographic information (age, gender, years of experience in the company, company information), whilst the second part consisted of statements on e-Procurement, face-to-face communication and their effect on supplier relationship to achieve the aim and objective of this research. The survey questions were arranged on a 5 point Likert scale from 'Strongly Agree' (5) to 'Strongly Disagree' (1).

A purposive sampling technique was used to choose respondents relevant to the research (Saunders et al., 2009). The employees included senior managers, managers, assistant managers and other employees working in the procurement departments. The selfadministered questionnaire was used to gather information from the employees. 50 questionnaires were sent to different procurement professionals and 37 questionnaires were returned. The sample included Supply Chain Managers - as suppliers, Procurement Managers - as buyers, and other Operations Managers. Key technologies used by these organisations largely focussed on the use of email, fax and videoconferencing for communication with their suppliers (i.e. 83.87\%).

Table 4 shows the list of all of the instrument questions and their relevant codings, whilst Table 5 and Table 6 show those particular pairwise instrument responses which were significant at $p<0.01$ and $p<0.05$, and which had the highest frequency counts respectively. Overall, there is a wide range of correlation across the entire dataset with the interesting observation that specific SRM factors do not contribute strongly (even in frequency of significant correlations) in the view of the respondents. Indeed the instrument results show that various e-Procurement (and hence SRM) technologies are seen to be more important - particularly as far as systems integration (EDI1) and doing business online (EAUCT1) are concerned. Table 6 highlights that there are as many negative as there are positive pairwise correlations with the highest correlation (DEMO7 - DEMO5, 0.686, $p<$ $0.01)$ signifying another interesting result in that age (and hence possibly seniority) as well as size of company is a determinant as far as SRM is concerned.

\section{Insert Table 4 here}

Equally at the other end of the scale, investment in nurturing relationships has a negative correlation with trust being built upon face-to-face communication (SRM3 - FACE5, -0.587, $p<0.01$ ). The remainder of the positive and significant correlation factors are not as high in a correlation sense although $25.6 \%$ of the survey questions are significant at $p<0.01$ as 
compared to $55.8 \%$ at $p<0.05$. Hence all of the positively correlated factors centre around the benefits that technology can provide for SRM and e-Procurement (hence actually viewing these as sustainable strategies in their own right). It may also be highlighting that if appropriate technologies are available to integrate buyer-supplier systems, a greater emphasis can be placed on the human side of managing SRM (hence the inclusion of societal and stakeholder elements from the SOM world into the SRM context).

\section{Insert Table 5 here}

\section{Insert Table 6 here}

The negative pairwise correlations appear to be mainly connected with a lack of reliance upon physical-virtual relationships (possibly denoting impact of trust and time given to building a buyer-supplier relationship). It is also interesting to note that faster communication does not necessarily appear to reduce lead time in (OTHERS1 - EDI3) - although the use of online marketplaces to select suppliers maybe due to the type of technology used rather than the usage of it.

In order to now relate these SRM responses to the SOM, each pairwise relationship given in the correlation Tables 4-6 were split and aligned to the SRM factors from Table 3 to see if there was any congruence and fit with SOM variables. This alignment and mapping is shown in Table 7, where once again the frequency of aligned values and variables has been tabulated to give a count of (effectively what are) the "stocks" of the archetype and the "flows" of the archetype. This mapping seeks to relate each survey question to its SRM-SOM counterpart from Table 3. Hence it can be seen that there is are ultimately now just 8 core SOM components (SS2, LGOM1, ES2, ES3, EVS2, ES4, EVS1 and SS1) that are relatable, based upon those statistically significant SRM response correlations identified early.

Table 7 provides a ranking of the SOM factors from the dataset which themselves correlate and resonate most closely to the SRM survey questions. Hence for example, ECAT3 (online information about products) appears to have a stronger linkage with SOM factors SS2 (improved relationships with external stakeholders) first and EVS2 second (products and services) and so on and so forth for the remaining factors in the list. By counting the occurrences of the key factors (i.e. number of first factors, as denoted by the frequency rank column in Table 6), the authors suggest that the SRM components of this study relate to the SOM factors of social sustainability (SS), lean and green OM (LGOM), Economic sustainability (ES) and Environmental Sustainability (EVS) factors. This thereby highlights 
that SRM components are somehow and somewhat embedded within the SOM landscape and in fact are inherent in terms of the realisation of the SRM platform of e-Procurement.

\section{Insert Table 7 here}

\subsection{The Finalised SRM-SOM SA}

Noting the preceding sections in terms of aligning the SRM response survey data (Tables 46) to the SOM factors in Table 3, the conceptual SA of Figure 3 can now be updated, by using Table 7. This updated SA of the SOM-SRM relationship is shown in Figure 4. The authors arranged the stocks of the archetype around the 8 ranked frequency correlation factors from Table 6. Following this, the authors then proceeded to cluster and link together shared SOM-SRM components in a pairwise fashion. For example, SS2 (as the stock) has a number of associated flows that lead on from one to another - thus FACE2, FACE4, FACE6 etc from Table 7 form a flow around SS2. However, EVS2 and hence ECAT1 and ECAT 2 are also interrelated through their relationship to each other - thereby allowing additional linkages to be formed. In doing so, the authors have refined the archetype based upon analysis of the empirical SRM e-Procurement survey.

\section{Insert Figure 4 here}

\section{Discussion}

What does this archetype show and how and why does this differ from that initially presented in Figure 2? Ultimately the SA has developed from beyond the "Accidental Adversaries" stage (of buyer and supplier) and noting the SOM-SRM inter-relationships developed thus far through a qualitative-quantitative approach into a more "traditional" systems dynamics model inter-related causal factors. In fact upon closer inspection it can be seen that what might be perceived to be closed internal loops within this revised diagram that might relate to either buyer or supplier behaviour, have little to bear on the wider implications of supplier relationship management. This is due to these factors being isolated and not connected with the wider causal flows in this case. A step-through of the SA is now carried out in order to understand it better.

Starting from the "Products and services" loop, there are positive impacts upon using online information to improve upon order generation efficiency. This has a direct and positive impact upon online pricing, which facilitates communication (i.e. the outer left hand side loop of the "Improved relationship with stakeholders" loop. Following the direction of the loop clockwise from here, the continuous and timely information that is shared between 
stakeholders has a negative impact on managing supplier relationships. This could be due to the effects of sharing information only electronically or as a result of an arms-length SRM for example. If some face-to-face communication between buyers and suppliers is carried out, perversely, and as seen by market participants, online transactional relationships would be seen as supportive of the buyer/supplier relationship by others. Clearly however, there is a large volume of factors which centre around improving the relationship with stakeholders and hence it is the centre of the archetype here which defines the root success of a combined SOM-SRM view of e-Procurement. This also bears out the findings from a similar systems map of sustainable petroleum operations by Duran-Encalada and Paucar-Caceres (2011) who also identified stakeholder motivations as being critical to their particular sustainability model too.

Finally it can be seen that both "Economic Performance" and "Equity within the organisation" loops are not connected to the rest of the archetype, even though there may have been strong and significant correlations between the SOM-SRM factors identified previously. This suggests that these factors are not inherently part of the system but play a crucial independent role - perhaps in regulating the strength and outcome of the underlying flows and dynamic nature of the relationships.

\section{Conclusions}

We have shown a method and output for developing a systems archetype to describe and exploratore, the relationship between SRM and concepts of SOM. By selecting a system archetype to match and describe the problem domain of interest (in this case, SRM and the e-Procurement function in particular), the authors henceforth set out to empirically gather data to evaluate the factors identified in the literature pertaining to both SOM and SRM. Through an analysis of the SRM survey data, key correlations were identified which were then ranked and through pairwise analysis were then aligned and associated with fundamental SOM concepts distilled from the literature which also were relevant and appropriate to the SRM / e-Procurement area of interest. Following this the authors were able to present a revised archetype model based upon the aforementioned alignment of SRM survey correlated data and reduced literature review SOM factors. The revised SA model was then walked through to discuss and explore deeper considerations relating to the topical area in question.

This approach provides both academics and practitioners with a method which is based upon well understood and traditional notions of quantitative data gathering and analysis (the survey) combined with a qualitative critical reasoning protocol (the systems archetype). In 
doing so, the work managed in developing an alternate description of a research design and strategy.

The results (both quantitatively and qualitatively) suggest that there is significant and positive relationship between different e-Procurement technologies (EDI, e-Marketplace, eCatalogue, e-Auctions, others) and supplier relationship, and support the hypothesis that there is a positive relationship between face-to-face communication and supplier relationships. In terms of the system archetype developed, this shows that different eProcurement technologies have little direct impact on supplier relationships, although noting that separate stakeholder-driven interventions may provide a benefit and realisation to sustainable operations goals and objectives, while face-to-face communication has a direct impact on the supplier relationship. Certainly managing relationships is a core factor when considering SOM factors aligned to the SRM context of e-Procurement.

The study concludes that the organisations surveyed are not using technology via eProcurement as a means to end in order to sustain their SRM. Indeed this reveals that eProcurement technologies themselves do not impact on the buyer-supplier relationship, but help to indirectly contribute to sustainable and lean methods of operation. The results also suggest that whatever type of SRM might be in place between the buyer and supplier, arm's length or partnership, fundamentally there are underlying and inherent relationships based upon stakeholder engagement. This is certainly bourne out by the results which will also show that company size and experience in managing suppliers have a considerable correlation and significant impact. This research has shown that the systems archetype and systems thinking methods can be applied to an empirical study - moreover the approach has attempted to also show the benefit of using such techniques in uncovering causal interrelationships. Indeed such thinking has lead to other novel applications of systems thinking such as in the modelling of policy activity too (Newsome, 2008). The authors suggest that future research in this area build upon the findings presented in terms of developing and formalising methods to enhance and validate archetypes in more traditional methodological scenarios. The researchers also intend to progress and refine this work from beyond the

pilot study (and limited sample) to a large sample size in order to investigate the effects of scale and generalisation that this method can provide.

\section{References}

Aboelmaged, M.G. (2010). 'Predicting e-procurement adoption in a developing country: An empirical integration of technology acceptance model and theory of planned Behaviour', Industrial Management \& Data Systems, 110(3) pp.392-414. 
Ambrose,E., Marshall, D., Fynes,B., and Lynch, D. (2008). 'Communication media selection in buyer-supplier relationships', International Journal of Operations \& Production Management, 28(4) pp.360-379.

Attaran, M., (2001). 'The coming age of E-procurement', Industrial Management \& Data Systems, 101(4) pp.177-181.

Atkinson, C. J. and Checkland, P. B. (1988). extending the metaphor 'System' Human Relations, 41(10), 709-725.

Bakker, E., Zheng, J., Knight, L. and Harland, C. (2008), 'Putting e-commerce adoption in a supply chain context', International Journal of Operations \& Production Management, 28(4) pp.313-330.

Bell, S., and Morse, S. (2007) 'Problem structuring methods: theorizing the benefits of deconstructing sustainable development projects', Journal of the Operational Research Society, $58: 576-87$.

Bettley, A. and Burnley, S. (2008). Towards Sustainable Operations Management Integrating Sustainability Management into Operations Management Strategies andPractices, Handbook of Performability Engineering, Springer.

Braun, W. (2002). The system archetypes. Available from: http://www.uniklu.ac.at/ gossimit/pap/sd/wb_sysarch.pdf [October 2011]

Carr, S., A and Kaynak, H. (2007). 'Communication methods, information sharing, supplier development and performance; An empirical study of their relationships', International Journal of Operations \& Production Management, 27(4) pp.346-370

Carter, T.C. (2003). Supplier Relationship Management: Models, considerations and implications for DOD. Available at: www.stormingmedia.us/45/4502/A450224.pdf

Chase, R. B., Jacobs, F. R., and Aquilano, N. J. (2006). Operations management for competitive advantage (11 $11^{\text {th }}$ Ed.) New York: McGraw-Hill Irwin.

Checkland, P.B. (1981). Systems Thinking, Systems Practice, John Wiley \& Sons, Chichester.

Checkland, P. B. and Scholes, J. (1997). Soft Systems Methodology in action, Wiley \& Sons, Chichester.

Choy, K.L., Lee, W.B. and Lo, V. (2004). 'An enterprise collaborative management system a case study of supplier relationship management', Journal of Enterprise Information Management, 17(3): 191-207.

Corbet, L. M. (2009). 'Sustainable Operations Management: A Typological Approach', Journal of Industrial Engineering and Management, 2(1): 10-30.

Davila, A., Gupta, M. and Palmer, R. (2003). 'Moving procurement systems to the Internet: The adoption and use of e-procurement technology models', European Management Journal, 21(1) pp.11-23 
Day, M., Magnan, G., Webb, M. and Hughes, J. (2008). 'Strategies supplier relationship management', Supply Chain Management Review, 4: 40-8.

Duran-Encalada, J.A., and Paucar-Caceres, A. (2011). A system dynamics sustainable business model for Petroleos Mexicanos (Pemex): case based on the Global Reporting Initiative, Journal of the Operational Research Society, $1: 1-14$.

Dyer, J.H., Cho, D.S. and Chu, W. (1998). 'Strategic supplier segmentation: the next "Best Practice" in supply chain management', California Management Review, 40(2): 57-77.

Eulálio,G., Campelo F. and Stucky, W. (2007). 'The Supplier Relationship Management Market Trends', World Academy of Science, Engineering and Technology, 28: 105-110.

Forrester, J.W. (1961). Industrial Dynamics. Pegasus Communications: Waltham, MA

Forrester, J.W. (1994). System dynamics, systems thinking, and soft OR. System Dynamics Review, 10(2-3): 245-256.

Gebauer, J., Beam, C. and Segev, A. (1998) Impact of internet on procurement. Available at: http://www.dau.mil/pubscats/PubsCats/AR\%20Journal/arq98/beam.pdf [Accessed on 15th July 2011

Gunasekaran, A., McGaughey, E.R., Ngai, E.W.T. and Rai, B.K. (2009). 'E-Procurement adoption in the Southcoast SMEs', Int. J. Production Economics, 122(1) pp.161-175.

Iskandar, B.Y., Kurokawa, S. and Blanc, L.L. (2001). 'Adoption of electronic data interchange: the role of buyer-supplier relationships', Engineering Management, IEEE Transactions, 48(4) pp. 505-17.

Jalal, S.F, Chaharsooghi, S.K.C ,Limayem, M. (2009). 'Simplifying procurement process through e-commerce in B2B market of Iran', Asia Pacific Management Review, 14(4) pp. 427-442

Jonathan, H. (2010). ;What is Supplier Relationship Management and Why Does it Matter?', DILForientering. Available at: http://www.vantagepartners.com/ISM_DILF_What_is_SRM.aspx.

Kleindorfer, P. R., Singhal, K. and Wassenhove, L. N. V. (2005). 'Sustainable Operations Management', Production and Operations Management, 14(4): 482-492.

Kwon, I-W.G. and Suh, T. (2004). 'Factors affecting the level of trust and commitment in supply chain relationships', The Journal of Supply Chain Management, 40(2): 4-14.

Lane, D. C. (1993). With a Little Help from Our Friends. In Enrique Zepeda, \& Jose A. DMachuca (ed.). The Role of Strategic Modelling in International Competitiveness. Proc. International System Dynamics Conference, pp. 235-244, Cancun, Mexico: System Dynamics Society, 49 Bedford Rd., Lincoln, MA, 01773, USA.

Linton, J. D., Klassen, R. D., and Jayaraman, V. (2007). 'Sustainable supply chains: An introduction', Journal of Operations Management, 25: 1075-1082. 
Luscombe, B. (2010) Why E-Mail May Be Hurting Off-Line Relationships. Available at:http://www.time.com/time/health/article/0,8599,1998396,00.html\#ixzz1UHwTGS2M [Accessed 12 July 2011].

Lysons, K. and Farrington, B. (2012). Purchasing and Supply Chain Management. 8th edn. London: Pearson Education Limited.

Moeller, S., Fassnacht, M. and Klose, S. (2008). 'A Framework for Supplier Relationship Management (SRM)', Journal of Business-to-Business Marketing, 13(4):69-94.

Monczka, R.M., Callahan, T.J. and Nichols, E.L. (1995). 'Predictors of relationships among buying and supplying firms', International Journal of Physical Distribution \& Logistics Management, 25(10) pp.45-59.

Monczka, R.M., Handfield, R.B., Scannell, T.V., Ragatz, G.L. and Frayer, D.J. (2000). New Product Development: Strategies for Supplier Integration, Milwaukee, WI: ASQ Quality Press.

Meier, R.L., Humphreys, M.A. and Williams, M.R. (1998). 'The role of purchasing in the agile enterprise', International Journal of Purchasing and Materials Management, 34(4): 39-45.

Mingers, J. and Rosenhead, J. (2004). Problem structuring methods in action. European Journal of Operational Research, 152: 530-554.

Murray J.G. (2009). 'Towards a common understanding of the differences between purchasing, procurement and commissioning in the UK public sector', Journal of Purchasing \& Supply Management, 15(3) pp.198-202.

Newsome, I.M. (2008). Using system dynamics to model the impact of policing activity on performance, Journal of the Operational Research Society, $59: 164$ - 170.

Nguyen, T.D. \& Nguyen, T.T.M. (2011). 'Enhancing relationship value between manufacturers and distributors through personal interaction Evidence from Vietnam', Journal of Management Development, 30(4) pp.316-328.

Osmonbekov, T., Bello, D.C. and Gilliland, D.I. (2002). 'Adoption of electronic commerce tools in business procurement: enhanced buying center structure and processes, The Journal of Business \& Industrial Marketing, 17(2-3) pp. 151-166.

Park, J., Shin, K., Chang, T.W and Park,J. (2010). 'An integrative framework for supplier relationship Management', Industrial Management \& Data Systems, 110(4) pp495-515

Pinnington, B.D. and Scanlon, T.J. (2009). 'Antecedents of collective-value within businessto-business relationships', European Journal of Marketing, 43(1/2) pp.31-45.

Poirier, C.C. (2010). Supplier Relationship Management: An Advanced Supply Chain Management Technique. Available at: http://www.scribd.com/doc/39098530/SRM AnAdvanced-SCM-Technique. 
Rai, A., Tang, X., Brown, P. and Keil, M. (2006). 'Assimilation patterns in the use of electronic procurement innovations: A cluster analysis', Information \& Management, 43(3) pp.336-349.

Senge, P., Kleiner, A., Roberts, C., Ross, R.B., \& Smith, B.J. (1994). The Fifth Discipline Fieldbook. New York: Doubleday.

Sharif, A.M. (2005). Can systems dynamics be effective in modelling dynamic business systems?, Business Process Management Journal, 11 (5) : 612 - 615.

Sterman, J.D. (2000). Business Dynamics, Systems Thinking and Modeling for a Complex World. Irwin/ McGraw-Hill: New York

Tatsis, V., Mena, C., Van Wassenhove, L., and Whicker, L. (2006). 'E-procurement in the Greek food and drink industry', Journal of Purchasing and Supply management, 12(2) pp. 63-74.

Verespej, M. (2002). 'E-procurement Explosion', Industry Week, 251 (2) pp.8-24.

Voorhuis , J. and van Loo, M. (2010). 'Strategic Supplier Relationship Management', Accenture, Available

at: http://www.accenture.com/SiteCollectionDocuments/PDF/Accenture Strategic Supplier_ Relationship_Management.pdf

Wagner, S.M and Essig, M. (2006). 'Electronic procurement applications and their impact on supplier relationship management', International. Journal of Services Technology and Management, 7(5/6) pp.439-462.

Winger, A.R. (2005). 'Face-to-face communication: Is it really necessary in a digitizing world?', Business Horizons, 48(3), pp.247-253.

Wognum, P.M., Fisscher, Olaf A.M., Weenink and, Suzanne, A.J. (2002). 'Balanced relationships: management of client-supplier relationships in product development, Technovation, 22(6) pp.341-351.

Wolstenholme, E. (2003). Towards the definition and use of a core set of archetypal structures in system dynamics. System Dynamics Review 19(1): 7-26.

Wolstenholme, E. (2004).Using generic system archetypes to support thinking and modelling. System Dynamics Review 20 341-356. 


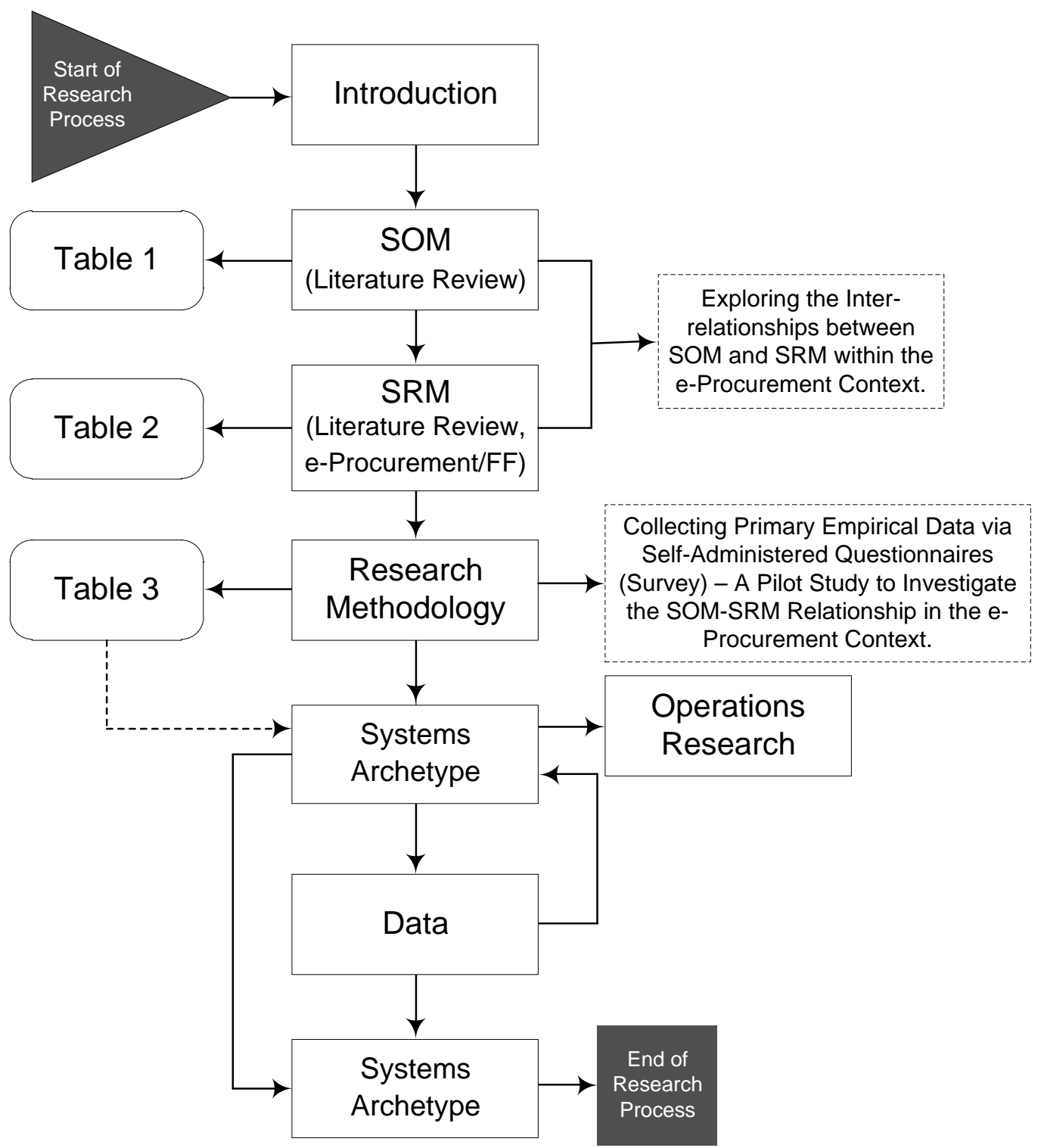

Figure 1. Research methodology 


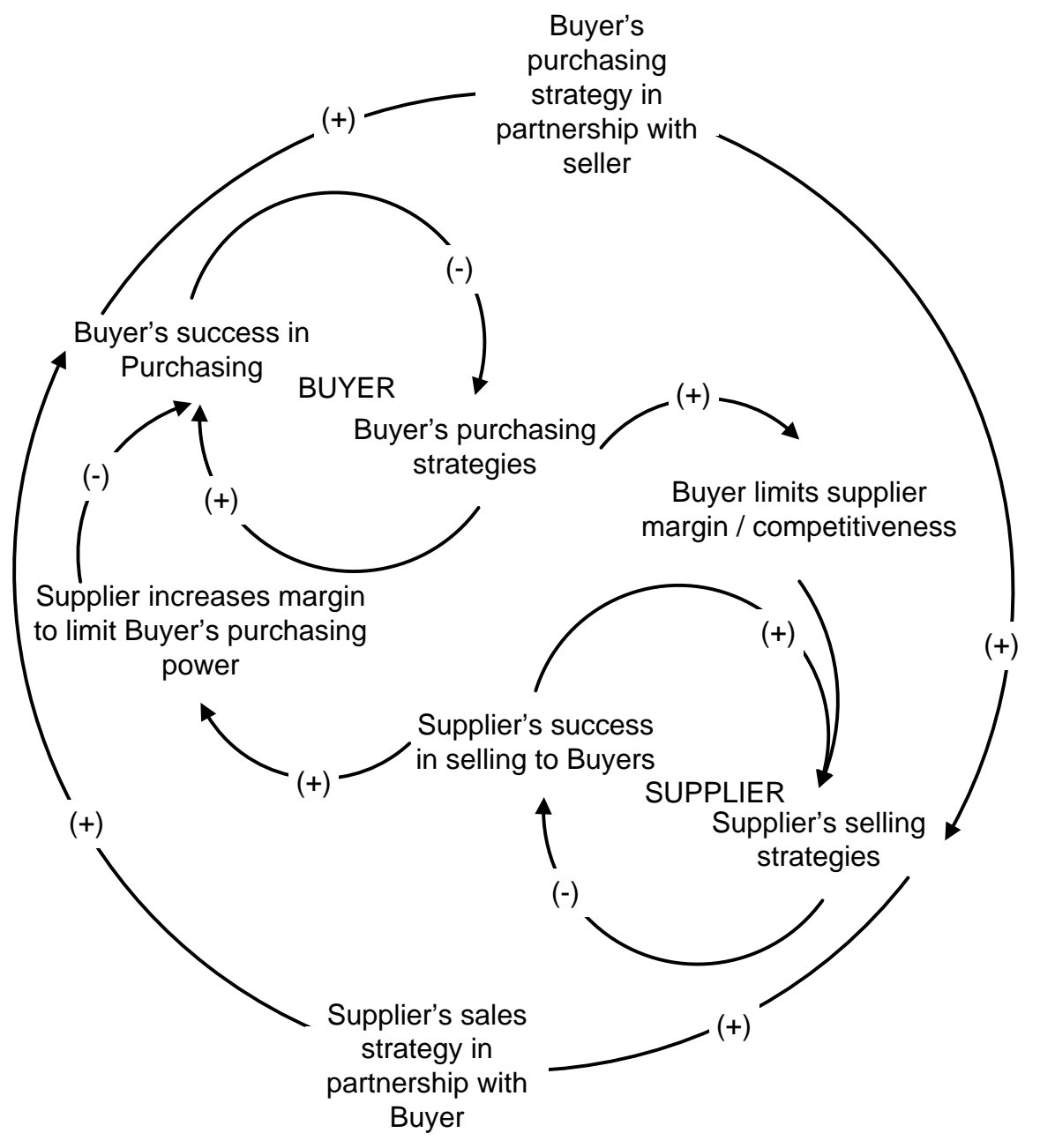

Figure 2. Combined Buyer-Supplier sub-archetypes arranged into the Accidental Adversaries archetype 


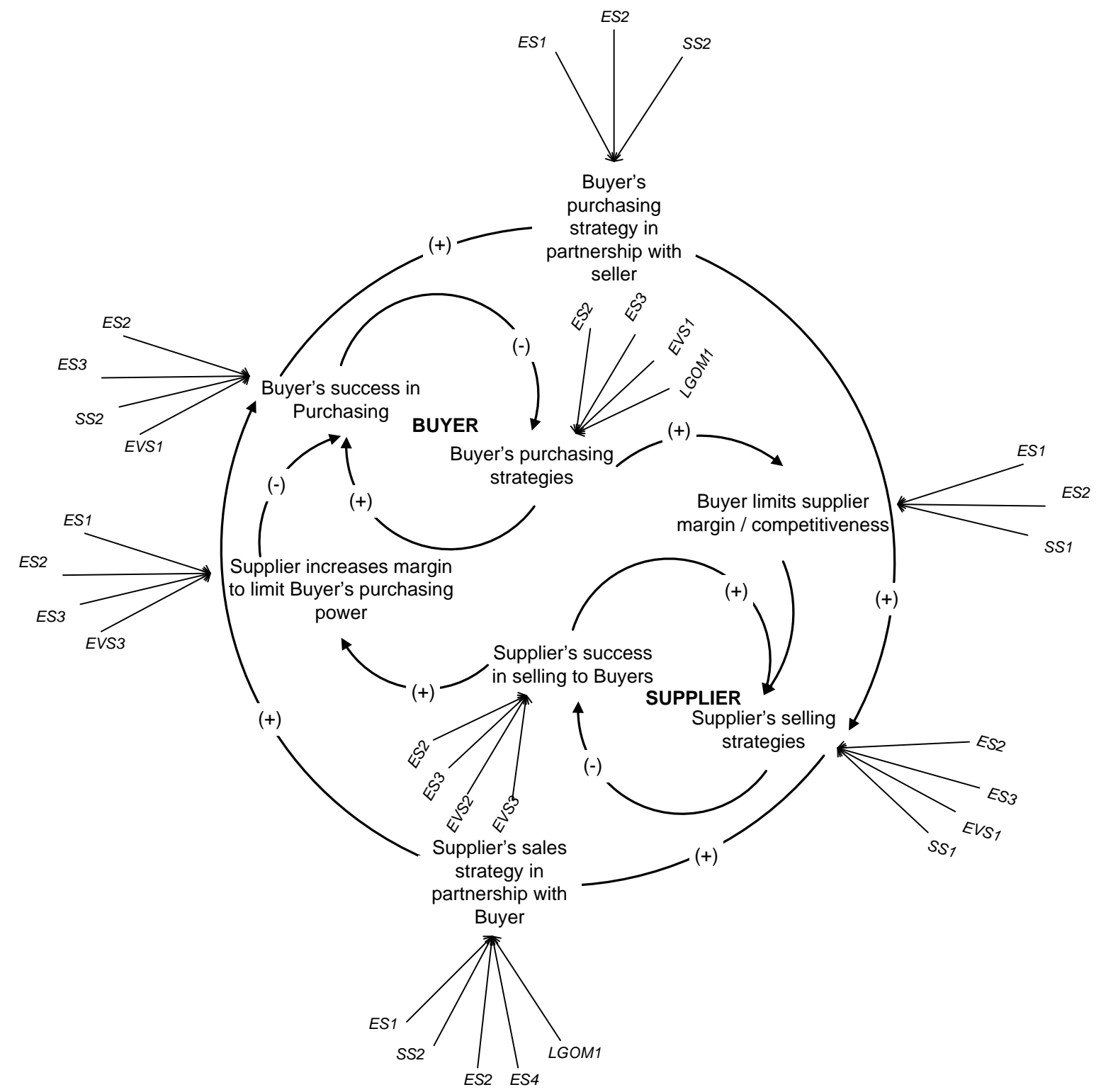

Figure 3. Conceptual SRM system archetype with key contributing SOM factors from Table 3 



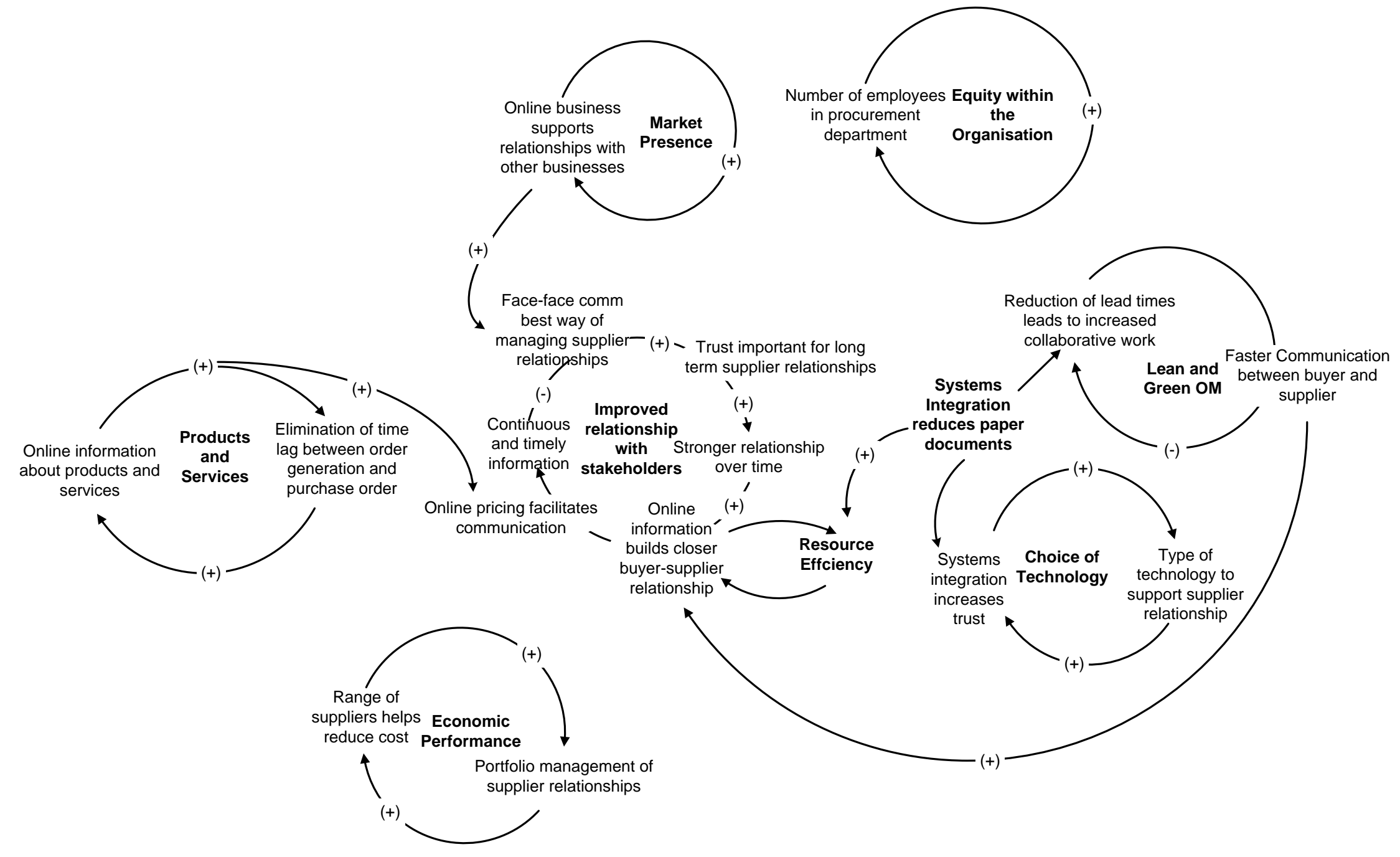

Figure 4. Updated system archetype for SRM-SOM 


\begin{tabular}{|c|c|c|c|}
\hline $\begin{array}{l}\text { Variable } \\
\text { Category }\end{array}$ & Sub-Variable & Description & References \\
\hline \multirow{4}{*}{$\begin{array}{l}\text { Economic } \\
\text { Sustainability }\end{array}$} & $\begin{array}{l}\text { Economic Impact on } \\
\text { Stakeholders }\end{array}$ & $\begin{array}{c}\text { Dividends, capital gains on stock, } \\
\text { taxes paid to government }\end{array}$ & Corbet (2009) \\
\hline & Choice of Technology & $\begin{array}{l}\text { Yield management, dematerialisation } \\
\text { of tangibles in service bundles, energy } \\
\text { efficiency improvements in lighting, air } \\
\text { conditioning, smart buildings }\end{array}$ & Corbet (2009) \\
\hline & Economic Performance & $\begin{array}{l}\text { Concerned with long-term financial } \\
\text { performance and competitiveness and } \\
\text { cost efficiency }\end{array}$ & $\begin{array}{c}\text { Corbet (2009); } \\
\text { Bettley and } \\
\text { Burnley (2008) }\end{array}$ \\
\hline & Market Presence & $\begin{array}{l}\text { To be well known in the market and } \\
\text { organisations to mark their ubiquitous } \\
\text { presence, focus on sustainability in } \\
\text { their supply chain }\end{array}$ & $\begin{array}{l}\text { Bettley and } \\
\text { Burnley (2008) }\end{array}$ \\
\hline \multirow{3}{*}{$\begin{array}{l}\text { Environmental } \\
\text { Sustainability }\end{array}$} & Resource Efficiency & $\begin{array}{l}\text { Process design focused on reducing } \\
\text { energy and natural resource } \\
\text { consumption in operations, production } \\
\text { planning and control focused on } \\
\text { reducing waste and optimising } \\
\text { materials usage } \\
\end{array}$ & Corbet (2009) \\
\hline & Products and Services & $\begin{array}{l}\text { Improved and efficient use of } \\
\text { resources }\end{array}$ & $\begin{array}{c}\text { Bettley and } \\
\text { Burnley (2008) }\end{array}$ \\
\hline & $\begin{array}{l}\text { Remanufacturing and } \\
\text { Closed-Loop Supply } \\
\text { Chains }\end{array}$ & $\begin{array}{l}\text { Focusing on reverse logistics, } \\
\text { disassembly and testing whilst also } \\
\text { paying more attention to product } \\
\text { reacquisition and remarketing }\end{array}$ & $\begin{array}{l}\text { Corbet (2009); } \\
\text { Kleindorfer et al., } \\
\quad(2005)\end{array}$ \\
\hline \multirow[b]{2}{*}{$\begin{array}{l}\text { Social } \\
\text { Sustainability }\end{array}$} & $\begin{array}{l}\text { Equity within } \\
\text { Organisation }\end{array}$ & $\begin{array}{l}\text { Bringing reforms in operational } \\
\text { practices to engage all staff in carbon } \\
\text { neutral improvement activities }\end{array}$ & Corbet (2009) \\
\hline & $\begin{array}{l}\text { Improved Relationships } \\
\text { with External } \\
\text { Stakeholders }\end{array}$ & $\begin{array}{l}\text { limproved financial performance from } \\
\text { brand development leads to more } \\
\text { secure jobs, regular voluntary } \\
\text { information on progress issued. }\end{array}$ & Corbet (2009) \\
\hline $\begin{array}{l}\text { Lean and } \\
\text { Green } \\
\text { Operations } \\
\text { Management }\end{array}$ & $\begin{array}{l}\text { Improved Tools and } \\
\text { Management Systems } \\
\text { for Better Product and } \\
\text { Process Design. }\end{array}$ & $\begin{array}{l}\text { Operations management attempting to } \\
\text { use the tools and concepts of lean } \\
\text { operations to add green metrics to the } \\
\text { measures of excellence organisations } \\
\text { employ in assessing business } \\
\text { processes }\end{array}$ & $\begin{array}{l}\text { Kleindorfer et al., } \\
\text { (2005) }\end{array}$ \\
\hline $\begin{array}{l}\text { Maximising } \\
\text { Value Across } \\
\text { the Supply } \\
\text { Chain }\end{array}$ & - & $\begin{array}{l}\text { Besides the usual processing of raw } \\
\text { material to delivery to the end } \\
\text { consumer, focusing on including the } \\
\text { design activities, dealing with by- } \\
\text { products of manufacture or use and } \\
\text { end-of-life processes of recovery or } \\
\text { disposal }\end{array}$ & $\begin{array}{l}\text { Linton et al., } \\
\quad(2007)\end{array}$ \\
\hline
\end{tabular}

Table 1: Key SOM Variables from a review of the literature 


\begin{tabular}{|c|c|c|}
\hline Variables & Description & References \\
\hline $\begin{array}{l}\text { Responsiveness to } \\
\text { Volatile Product Costs }\end{array}$ & $\begin{array}{l}\text { The unsteadiness of product markets is always } \\
\text { anticipated to prolong. Strong supplier relationships } \\
\text { can give an organisation the capability to act in } \\
\text { response positively to volatile product costs. }\end{array}$ & $\begin{array}{l}\text { Voorhuis and } \\
\text { van Loo (2010) }\end{array}$ \\
\hline Technology and Systems & $\begin{array}{l}\text { A multitude of technology solutions are alleged to } \\
\text { facilitate SRM. These systems assist in gathering and } \\
\text { tracking supplier performance data across different } \\
\text { sites, business units, and/or regions. It is vital to note } \\
\text { that SRM software, cannot be implemented in the } \\
\text { absence of the other business structure and process } \\
\text { changes that are recommended as part of } \\
\text { implementing SRM as a strategy. }\end{array}$ & Jonathan (2010) \\
\hline Reduced Supply Risks & $\begin{array}{l}\text { Businesses depend more on their upstream supply } \\
\text { chain partners to get their own products/services } \\
\text { delivered to customers on time and with quality. } \\
\text { Having strong supplier relationships with better view } \\
\text { into supplier data and processes allows organisations } \\
\text { to more proactively manage and reduce risks (e.g. } \\
\text { risks of quality, manufacturing and logistics). }\end{array}$ & $\begin{array}{l}\text { Voorhuis and } \\
\text { van Loo (2010) }\end{array}$ \\
\hline Cost Reductions & $\begin{array}{l}\text { SRM directly brings financial benefits once } \\
\text { implemented. Trust based relationships inspire } \\
\text { greater collaboration, generate opportunities for } \\
\text { increased innovation and lead to better efficiency, } \\
\text { which in turn unlock value and lower the cost of doing } \\
\text { business for both organisations. }\end{array}$ & $\begin{array}{l}\text { Voorhuis and } \\
\text { van Loo (2010) }\end{array}$ \\
\hline $\begin{array}{l}\text { Optimisation of } \\
\text { Performance }\end{array}$ & $\begin{array}{l}\text { In coordinating and automating the processes } \\
\text { concerned with the supplier integration and } \\
\text { communication, leads to optimised performance. }\end{array}$ & $\begin{array}{l}\text { Eulálio et al., } \\
\qquad(2007)\end{array}$ \\
\hline $\begin{array}{c}\text { Innovative Products and } \\
\text { Services }\end{array}$ & $\begin{array}{l}\text { Many companies are working to come out of the } \\
\text { downturn in better shape than before and be best } \\
\text { prepared for the upturn. They are striving to get ahead } \\
\text { of competition through new product development and } \\
\text { innovation, such as the automobile manufacturer now } \\
\text { focusing on products that use less energy. When } \\
\text { strong relationships are in place, companies and their } \\
\text { suppliers have the foundation to work together to } \\
\text { outperform the competition, bringing new products to } \\
\text { market more quickly and benefiting from continuing } \\
\text { innovations in products and services. As Gartner } \\
\text { notes, properly managed supplier relationships can } \\
\text { contribute to enterprise innovation and growth, while a } \\
\text { poorly managed supply base will drive up costs and } \\
\text { slow new product initiatives. }\end{array}$ & $\begin{array}{l}\text { Voorhuis and } \\
\text { van Loo (2010) }\end{array}$ \\
\hline $\begin{array}{l}\text { Continuity in } \\
\text { Improvement }\end{array}$ & $\begin{array}{l}\text { Implementing the appropriate strategy, processes, } \\
\text { measures, technologies, standards and focus on a } \\
\text { selected group of suppliers can develop } \\
\text { supplementary value on a permanent basis. }\end{array}$ & $\begin{array}{l}\text { Voorhuis and } \\
\text { van Loo (2010) }\end{array}$ \\
\hline Enhanced Sustainability & $\begin{array}{l}\text { The move towards SRM with collaboration in focus, an } \\
\text { effective and efficient utilisation of resources, naturally } \\
\text { leads to a 'greener' supplier relationship. }\end{array}$ & $\begin{array}{l}\text { Voorhuis and } \\
\text { van Loo (2010) }\end{array}$ \\
\hline Mutual Collaboration & $\begin{array}{l}\text { Any supplier-facing business practices facilitated by } \\
\text { collaborative software and that enable organisations } \\
\text { to work with their supplier base for shared success. }\end{array}$ & $\begin{array}{l}\text { Ambrose et al. } \\
\text { (2008) }\end{array}$ \\
\hline
\end{tabular}

Table 2: Key SRM Variables from a review of the literature 


\begin{tabular}{|c|c|c|}
\hline \multicolumn{2}{|c|}{ SOM Variables } & SRM Corresponding Variables \\
\hline \multirow{4}{*}{$\begin{array}{c}\text { Economic } \\
\text { Sustainability }\end{array}$} & $\begin{array}{c}\text { ES1 - Economic Impact on } \\
\text { Stakeholders }\end{array}$ & Efficiency and Effectiveness \\
\cline { 2 - 3 } & ES2 - Choice of Technology & Technology and Systems \\
\cline { 2 - 3 } & ES3 - Economic Performance & Cost Reductions \\
\cline { 2 - 3 } $\begin{array}{c}\text { Environmental } \\
\text { Sustainability }\end{array}$ & ESS - Market Presence & Innovative Products and Services \\
\cline { 2 - 3 } $\begin{array}{c}\text { Social } \\
\text { Sustainability }\end{array}$ & EVS2 - Products and Services & Innovative Products and Services \\
\cline { 2 - 3 } & EVS3 - Remanufacturing and & \\
\cline { 2 - 3 } $\begin{array}{c}\text { Lean and } \\
\text { Green } \\
\text { Operations } \\
\text { Management }\end{array}$ & SS1 - Equity within Organisation & Improved Sustainability \\
\hline
\end{tabular}

Table 3: Identified SOM-SRM factors 


\begin{tabular}{|c|c|}
\hline Coding & Question \\
\hline DEMO1 & Please tick your age group \\
\hline DEMO2 & Please tick your gender \\
\hline DEMO3 & How long have you worked in the current organisation? \\
\hline DEMO4 & Your Job Title \\
\hline DEMO5 & Please tick company size group \\
\hline DEMO6 & Please tick the type of industry your organization is in \\
\hline DEMO7 & Please tick your company age group \\
\hline DEMO8 & $\begin{array}{l}\text { Please tick the number of employees in Procurement Department Does your organization } \\
\text { categorize or differentiate between different items purchased using any }\end{array}$ \\
\hline DEMO9 & particular methods (Pareto, Kraljic, etc)? \\
\hline DEMO10 & What kind of technology does your company use to support your supplier relationship? \\
\hline DEMO11 & Who is responsible for managing the relationship with the supplier? \\
\hline EAUCT1 & Doing online business helps build relationship with other businesses \\
\hline EAUCT2 & Structured process of online purchases helps reduce ordering time \\
\hline EAUCT3 & In eAuctions, bids that are replaced by higher bids eventually drive prices higher \\
\hline ECAT1 & $\begin{array}{l}\text { E-Catalogues provide online information about products and services Online information about } \\
\text { products eliminates time lag between order generation and issue of } \\
\text { purchase orders }\end{array}$ \\
\hline ECAT3 & Online information about products facilitates real two-way communication \\
\hline ECAT4 & Online information helps build closer buyer-supplier relationships \\
\hline EDI1 & System integration between systems helps increase trust between parties \\
\hline EDI2 & Systems integration helps reduce paper documents (PO, acknowledgements, invoices) \\
\hline EDI3 & EDI reduces lead times as buyers and suppliers can work together \\
\hline EDI4 & Integration of functions between buyer and suppliers promotes a long term relationship \\
\hline FACE1 & The amount of communication with our supplier is about right. \\
\hline FACE2 & Continuous and timely information is important between buyer and supplier \\
\hline FACE3 & Face to face communication is most effective way of establishing relationships with supplier. \\
\hline FACE4 & Trust is more important ingredient for establishing long term relationship with suppliers \\
\hline FACE5 & $\begin{array}{l}\text { Face to face communication helps increase trust between buyer and supplier As relationships are } \\
\text { managed by humans, so face to face communications' are the most }\end{array}$ \\
\hline FACE6 & $\begin{array}{l}\text { appropriate way of managing relationships with supplier When the relationship requires consensus } \\
\text { building and / or conflict resolution, face to face }\end{array}$ \\
\hline FACE7 & communication is the most appropriate method \\
\hline FACE8 & Face to face communication is the most transparent way of communicating with suppliers. \\
\hline MARK1 & Use of marketplaces (websites) helps in better selection of suppliers \\
\hline MARK2 & Marketplaces provide a range of suppliers to help reduce cost \\
\hline MARK3 & Marketplaces reduce the time in selecting products and suppliers \\
\hline OTHERS1 & Faster communication between buyer and supplier is important \\
\hline OTHERS2 & Other channels of communication reduce the importance of face to face communication. \\
\hline OTHERS3 & Are ICT solutions the cheapest way to communicate with suppliers \\
\hline OTHERS4 & Suppliers prefer information communication technologies for relationship building \\
\hline SRM1 & The organisation fully understands the concept of supplier relationship management \\
\hline SRM2 & The organisation can easily replace one supplier with another supplier \\
\hline SRM3 & The organisation spends a lot of time and effort in nurturing the relationship with its suppliers \\
\hline SRM4 & The organisation manages a portfolio of relationships with different suppliers \\
\hline SRM5 & Our relationship with our suppliers is well coordinated \\
\hline SRM6 & Relationship with suppliers becomes stronger with the passage of time \\
\hline
\end{tabular}

Table 4. SRM instrument questions and codings 




\begin{tabular}{|c|c|c|c|c|c|c|c|c|c|}
\hline \multirow[b]{2}{*}{ Pair combination } & \multirow[b]{2}{*}{$p$} & \multirow[b]{2}{*}{$\mathbf{R}$} & \multirow[b]{2}{*}{$\mathbf{R}^{2}$} & \multirow[b]{2}{*}{$\begin{array}{l}\text { Adj. } \\
\mathbf{R}^{2}\end{array}$} & \multirow{2}{*}{$\begin{array}{l}\text { Std. } \\
\text { Error } \\
e\end{array}$} & \multicolumn{2}{|c|}{ Coefficients } & \multirow{2}{*}{$\begin{array}{l}\text { Sig. } \\
p\end{array}$} & \multirow[t]{2}{*}{ Description } \\
\hline & & & & & & $\begin{array}{c}\text { Intercept } \\
(x)\end{array}$ & $\begin{array}{c}\text { Constant } \\
(y)\end{array}$ & & \\
\hline $\begin{array}{l}\text { DEMO7 - } \\
\text { DEMO5 }\end{array}$ & $0.686^{* *}$ & 0.686 & 0.470 & 0.451 & 0.940 & 0.625 & 0.816 & 0.0000 & $\begin{array}{l}\text { There is some correlation between the age of a company and its size } \\
\text { (DEMO7 - DEMO5) }\end{array}$ \\
\hline $\begin{array}{l}\text { EAUCT1 - } \\
\text { ECAT1 }\end{array}$ & $0.633^{* *}$ & 0.633 & 0.400 & 0.379 & 0.708 & 1.051 & 0.888 & 0.0002 & $\begin{array}{l}\text { Strong positive correlation between doing business online to build } \\
\text { relationship outside of the supplier relationship and the provision of } \\
\text { online product/service information - hence social network of supplier } \\
\text { relationships help strengthen a single one (EAUCT1 - ECAT1) }\end{array}$ \\
\hline EDI1 - FACE7 & $0.555^{* *}$ & 0.555 & 0.308 & 0.283 & 0.679 & 1.107 & 0.783 & 0.0015 & $\begin{array}{l}\text { Some correlation between systems integration between parties and } \\
\text { face to face communication and conflict resolution to enable } \\
\text { consensus building (EDI1 - FACE7) }\end{array}$ \\
\hline $\begin{array}{l}\text { FACE7 - } \\
\text { OTHERS4 }\end{array}$ & $0.537 * *$ & 0.537 & 0.288 & 0.263 & 0.488 & 0.623 & 0.399 & 0.0022 & $\begin{array}{l}\text { Face to face communication for concensus building and conflict } \\
\text { resolution, correlates positively with a range of technologies for SRM } \\
\text { (FACE7 - OTHERS4) }\end{array}$ \\
\hline MARK2 - FACE6 & $0.497 * *$ & 0.497 & 0.247 & 0.220 & 0.878 & 0.982 & 0.624 & 0.0052 & $\begin{array}{l}\text { Some correlation between online marketplaces providing range of } \\
\text { suppliers at cost and face to face communications to manage supplier } \\
\text { relationship (MARK2 - FACE6) }\end{array}$ \\
\hline EAUCT2 - EDI4 & $0.496^{* *}$ & 0.496 & 0.246 & 0.219 & 0.702 & 1.223 & 0.489 & 0.0053 & $\begin{array}{l}\text { Structured online purchasing process correlates positively with } \\
\text { integrated buyer-supplier functions leading to long term relationship } \\
\text { (EAUCT2 - EDI4) }\end{array}$ \\
\hline FACE2 - DEMO8 & $0.492 * *$ & 0.492 & 0.242 & 0.215 & 0.506 & 1.041 & 0.506 & 0.0057 & $\begin{array}{l}\text { Timely information has a positive correlation with the number of } \\
\text { employees in the organisation (FACE2 - DEMO8) }\end{array}$ \\
\hline EDI1 - OTHERS4 & $0.468^{* *}$ & 0.468 & 0.219 & 0.191 & 0.721 & 1.171 & 0.491 & 0.0091 & $\begin{array}{l}\text { Some correlation between systems integration and a range of } \\
\text { technologies for SRM (EDI1 - OTHERS4) }\end{array}$ \\
\hline SRM6 - EDI2 & $0.434^{*}$ & 0.434 & 0.188 & 0.159 & 0.728 & 0.913 & 0.363 & 0.0165 & $\begin{array}{l}\text { Some correlation between developing relationship becoming stronger } \\
\text { over time and systems integration of business processes (SRM6 - } \\
\text { EDI2) }\end{array}$ \\
\hline $\begin{array}{l}\text { MARK2 - } \\
\text { OTHERS3 }\end{array}$ & $0.432 *$ & 0.432 & 0.187 & 0.157 & 0.913 & 1.317 & 0.535 & 0.0172 & $\begin{array}{l}\text { Marketplaces are a cost effective way to communicate with suppliers } \\
\text { (MARK2 - OTHERS3) }\end{array}$ \\
\hline $\begin{array}{l}\text { ECAT3 - } \\
\text { DEMO10 }\end{array}$ & $0.43^{*}$ & 0.430 & 0.185 & 0.156 & 0.753 & 1.231 & 1.019 & 0.0177 & $\begin{array}{l}\text { Some positive orrelation between online product information and } \\
\text { type of technology used to support the SRM (ECAT3 - DEMO10) }\end{array}$ \\
\hline ECAT4 - ECAT1 & $0.419 *$ & 0.419 & 0.176 & 0.146 & 0.832 & 1.360 & 0.590 & 0.0211 & $\begin{array}{l}\text { Providing online inforation about products and services helps build } \\
\text { closer buyer-supplier relationships (ECAT4 - ECAT1) }\end{array}$ \\
\hline MARK3 - EDI3 & $0.408^{*}$ & 0.408 & 0.166 & 0.137 & 0.794 & 1.469 & 0.490 & 0.0253 & $\begin{array}{l}\text { Marketplaces reduce product selection and lead times between buyers } \\
\text { and suppliers (MARK3 - EDI3) }\end{array}$ \\
\hline $\begin{array}{l}\text { SRM5 - } \\
\text { OTHERS3 }\end{array}$ & $0.405^{*}$ & 0.405 & 0.164 & 0.134 & 0.749 & 1.428 & 0.406 & 0.0263 & $\begin{array}{l}\text { Co-ordinated relationship with suppliers and a range of technologies } \\
\text { to manage SRM correlate positively togeher (SRM5 - OTHERS3) }\end{array}$ \\
\hline
\end{tabular}




\begin{tabular}{|c|c|c|c|c|c|c|c|c|c|}
\hline \multirow[b]{2}{*}{ Pair combination } & \multirow[b]{2}{*}{$p$} & \multirow[b]{2}{*}{$\mathbf{R}$} & \multirow[b]{2}{*}{$\mathbf{R}^{2}$} & \multirow[b]{2}{*}{$\begin{array}{l}\text { Adj. } \\
\mathbf{R}^{2}\end{array}$} & \multirow{2}{*}{$\begin{array}{c}\text { Std. } \\
\text { Error } \\
e\end{array}$} & \multicolumn{2}{|c|}{ Coefficients } & \multirow{2}{*}{$\begin{array}{l}\text { Sig. } \\
\qquad\end{array}$} & \multirow[t]{2}{*}{ Description } \\
\hline & & & & & & $\begin{array}{c}\text { Intercept } \\
(x)\end{array}$ & $\begin{array}{c}\text { Constant } \\
(y)\end{array}$ & & \\
\hline FACE2 - ECAT4 & $0.402^{*}$ & 0.402 & 0.162 & 0.132 & 0.532 & 1.228 & 0.255 & 0.0275 & $\begin{array}{l}\text { Timely information has a positive correlation with closer buyer- } \\
\text { supplier relationship (FACE2 - ECAT4) }\end{array}$ \\
\hline $\begin{array}{l}\text { DEMO2 - } \\
\text { DEMO11 }\end{array}$ & $0.401^{*}$ & 0.401 & 0.161 & 0.131 & 0.322 & 0.892 & 0.127 & 0.0280 & $\begin{array}{l}\text { Gender has a posisitve correlation to the person involved in } \\
\text { managing the supplier relationship (DEMO2 - DEMO11) }\end{array}$ \\
\hline $\begin{array}{l}\text { DEMO10 - } \\
\text { FACE7 }\end{array}$ & $0.398^{*}$ & 0.398 & 0.158 & 0.128 & 0.323 & 1.488 & 0.242 & 0.0295 & $\begin{array}{l}\text { The type of technology used for SRM has a positive relationship with } \\
\text { the face to face communication (concensus, conflict resolution) } \\
\text { between buyer and supplier (DEMO10 - FACE7) }\end{array}$ \\
\hline DEMO5 - EDI1 & $0.39 *$ & 0.390 & 0.152 & 0.122 & 0.999 & 1.825 & 0.518 & 0.0333 & $\begin{array}{l}\text { Company size is positive correlated to how systesm integration } \\
\text { between systems increases trust between parties (DEMO5 - EDI1) }\end{array}$ \\
\hline EDI4 - OTHERS4 & $0.381^{* *}$ & 0.381 & 0.145 & 0.114 & 0.758 & 1.251 & 0.401 & 0.0379 & $\begin{array}{l}\text { Integrated buyer-supplier functions which promote long term } \\
\text { relationships correlates positively with a preference for a range of } \\
\text { technologies for SRM (EDI4 - OTHERS4) }\end{array}$ \\
\hline DEMO5 - SRM4 & $0.375^{*}$ & 0.375 & 0.141 & 0.110 & 1.006 & 1.806 & 0.534 & 0.0410 & $\begin{array}{l}\text { Company size is positively related to how the organisation manages a } \\
\text { portfolio of relationships with different suppliers (DEMO5 - SRM4) }\end{array}$ \\
\hline $\begin{array}{l}\text { ECAT1 - } \\
\text { EAUCT3 }\end{array}$ & $0.375^{*}$ & 0.375 & 0.141 & 0.110 & 0.603 & 1.097 & 0.306 & 0.0409 & $\begin{array}{l}\text { Access to online product and service information correlates } \\
\text { positively to bid price escalation (ECAT1 - EAUCT3) }\end{array}$ \\
\hline DEMO11 - SRM4 & $0.374^{*}$ & 0.374 & 0.140 & 0.109 & 1.032 & 0.644 & 0.546 & 0.0416 & $\begin{array}{l}\text { Seniority correlates positively with the management of a portfolio of } \\
\text { supplier relationships (DEMO11 - SRM4) }\end{array}$ \\
\hline $\begin{array}{l}\text { MARK1 - } \\
\text { OTHERS1 }\end{array}$ & $0.373 *$ & 0.373 & 0.139 & 0.109 & 0.772 & 2.422 & 0.399 & 0.0422 & $\begin{array}{l}\text { Using marketplaces to select suppliers correlates positively with } \\
\text { faster communication between buyers and suppliers (MARK1 - } \\
\text { OTHERS1) }\end{array}$ \\
\hline $\begin{array}{l}\text { OTHERS1 - } \\
\text { MARK1 }\end{array}$ & $0.373 *$ & 0.373 & 0.139 & 0.109 & 0.722 & 0.904 & 0.349 & 0.0422 & $\begin{array}{l}\text { Markeplaces improve selection of suppliers, through faster } \\
\text { communication between buyer and supplier (OTHERS1 - MARK1) }\end{array}$ \\
\hline DEMO1 - FACE3 & $0.372^{*}$ & 0.372 & 0.138 & 0.107 & 0.919 & 2.518 & 0.518 & 0.0431 & $\begin{array}{l}\text { Age of respondent has a positive correlation to establishing face to } \\
\text { face communications with supplier (DEMO1 - FACE3) }\end{array}$ \\
\hline EDI3 - SRM6 & $0.372 *$ & 0.108 & 0.012 & $\overline{-} 0.024$ & 0.812 & 2.519 & -0.109 & 0.5692 & $\begin{array}{l}\text { Reduction of leadtime between supplier and buyer correlates } \\
\text { positively with strengthening relationship between suppliers (EDI3 - } \\
\text { SRM6) }\end{array}$ \\
\hline $\begin{array}{l}\text { DEMO10 - } \\
\text { FACE5 }\end{array}$ & $0.37 *$ & 0.370 & 0.137 & 0.106 & 0.327 & 1.441 & 0.246 & 0.0440 & $\begin{array}{l}\text { The type of technology used for SRM has a positive relationship with } \\
\text { the face to face communication (trust) between buyer and supplier } \\
\text { (DEMO10 - FACE5) }\end{array}$ \\
\hline DEMO2 - SRM3 & $0.368^{*}$ & 0.368 & 0.135 & 0.104 & 0.327 & 0.823 & 0.190 & 0.0455 & $\begin{array}{l}\text { Gender has a posisitve correlation to how the relationship is nurtured } \\
\text { with a supplier (DEMO2 - SRM3) }\end{array}$ \\
\hline DEMO8 - SRM3 & $0.368^{*}$ & 0.368 & 0.135 & 0.104 & 0.526 & 1.134 & 0.306 & 0.0455 & $\begin{array}{l}\text { Size of procurement organisation correlates positively with how the } \\
\text { organisation nurtures the relationship with suppliers (DEMO8 - } \\
\text { SRM3) }\end{array}$ \\
\hline
\end{tabular}




\begin{tabular}{|c|c|c|c|c|c|c|c|c|c|}
\hline \multirow[b]{2}{*}{ Pair combination } & \multirow[b]{2}{*}{$p$} & \multirow[b]{2}{*}{$\mathbf{R}$} & \multirow[b]{2}{*}{$\mathbf{R}^{2}$} & \multirow{2}{*}{\multicolumn{2}{|c|}{$\begin{array}{l}\text { Std. } \\
\text { Error } \\
e\end{array}$}} & \multicolumn{2}{|c|}{ Coefficients } & \multirow{2}{*}{$\begin{array}{l}\text { Sig. } \\
\quad p\end{array}$} & \multirow[t]{2}{*}{ Description } \\
\hline & & & & & & $\begin{array}{l}\text { Intercept } \\
(x)\end{array}$ & $\begin{array}{c}\text { Constant } \\
\text { (y) }\end{array}$ & & \\
\hline $\begin{array}{l}\text { DEMO10 - } \\
\text { FACE3 }\end{array}$ & $-0.381 *$ & 0.381 & 0.145 & 0.114 & 0.325 & 2.212 & -0.188 & 0.0380 & $\begin{array}{l}\text { Choice of SRM technology has negative correlation to face to face } \\
\text { communication for SRM (DEMO10 - FACE3) }\end{array}$ \\
\hline DEMO11 - SRM6 & $-0.393^{*}$ & 0.393 & 0.154 & 0.124 & 1.024 & 2.820 & -0.541 & 0.0317 & $\begin{array}{l}\text { Responsibility and role for managing relationship with supplier has } \\
\text { negative correclation with strength of relationship over time } \\
\text { (DEMO11 - SRM6) }\end{array}$ \\
\hline EDI2 - FACE4 & $-0.437^{*}$ & 0.437 & 0.191 & 0.162 & 0.869 & 3.500 & -0.833 & 0.0157 & $\begin{array}{l}\text { Systems integration efficiencies has a negative correlation with trust } \\
\text { and long term SRM (EDI2 - FACE4) }\end{array}$ \\
\hline ECAT2 - FACE4 & $-0.439 *$ & 0.439 & 0.193 & 0.164 & 0.605 & 2.833 & -0.583 & 0.0152 & $\begin{array}{l}\text { Online information that may improve order generation and PO } \\
\text { generation has a negative correlation to improving supplier trust } \\
\text { (ECAT2 - FACE4) }\end{array}$ \\
\hline MARK2 - ECAT3 & $-0.522 * *$ & 0.522 & 0.273 & 0.247 & 0.863 & 4.318 & -0.634 & 0.0031 & $\begin{array}{l}\text { Cost effectiveness of operating in an online marketplace has a } \\
\text { negative correlation to two-way communication (MARK2 - ECAT3) }\end{array}$ \\
\hline SRM3 - FACE5 & $-0.587^{* *}$ & 0.587 & 0.345 & 0.322 & 0.551 & 2.941 & -0.754 & 0.0006 & $\begin{array}{l}\text { Development and maintenance of supplier relationships has a } \\
\text { negative correlation with doing business online because you are } \\
\text { spending more time on it! (SRM3 - FACE5) }\end{array}$ \\
\hline
\end{tabular}

Note: *. Correlation is significant at the 0.05 level (2-tailed), ${ }^{* *}$. Correlation is significant at the 0.01 level (2-tailed)

Table 5: Key pairwise Correlations 


\begin{tabular}{|c|c|c|c|c|c|c|c|c|c|c|c|c|c|c|}
\hline Pair Combinations & 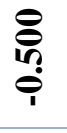 & $\begin{array}{l}\stackrel{P}{\tilde{f}} \\
\stackrel{+}{+}\end{array}$ & $\begin{array}{l}\hat{\text { Oे }} \\
\text { †े }\end{array}$ & 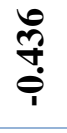 & $\begin{array}{l}\text { ָै } \\
\text { ஸे } \\
\text { 1 }\end{array}$ & 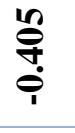 & 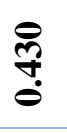 & 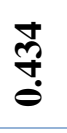 & S্: & ণั & $\begin{array}{l}\text { } \\
\stackrel{+}{+} \\
0\end{array}$ & $\begin{array}{l}\text { 占 } \\
\text { مُ } \\
0\end{array}$ & $\begin{array}{l}\mathscr{7} \\
\ddot{\theta}\end{array}$ & Count \\
\hline EAUCT1 & & & & & & & & & 1 & & & & 1 & 2 \\
\hline ECAT1 & & & & & & & & & & & & & 1 & 1 \\
\hline ECAT4 & & & & & & & & & 1 & & & & & 1 \\
\hline ECAT2 & & 1 & & & & & & & & & & & & 1 \\
\hline FACE4 & & 1 & & & & & & & & & & & & 1 \\
\hline ECAT3 & & & & & & & 1 & & & & & & & 1 \\
\hline DEMO10 & & & & & & & 1 & & & & & & & 1 \\
\hline EDI1 & & & & 1 & & & & & & & & 1 & & 2 \\
\hline FACE7 & & & & & & & & & & & & 1 & & 1 \\
\hline FACE8 & & & & 1 & & & & & & & & & & 1 \\
\hline EDI2 & & & 1 & & & & & & & & & & & 1 \\
\hline FACE4 & & & 1 & & & & & & & & & & & 1 \\
\hline FACE2 & & & & & & & & & & 1 & & & & 1 \\
\hline DEMO8 & & & & & & & & & & 1 & & & & 1 \\
\hline MARK2 & & & & & & & & & & & 1 & & & 1 \\
\hline FACE6 & & & & & & & & & & & 1 & & & 1 \\
\hline MARK3 & & & & & 1 & & & & & & & & & 1 \\
\hline FACE8 & & & & & 1 & & & & & & & & & 1 \\
\hline OTHERS1 & 1 & & & & & & & & & & & & & 1 \\
\hline EDI3 & 1 & & & & & & & & & & & & & 1 \\
\hline SRM4 & & & & & & 1 & & & & & & & & 1 \\
\hline EAUCT1 & & & & & & 1 & & & & & & & & 1 \\
\hline SRM6 & & & & & & & & 1 & & & & & & 1 \\
\hline EDI2 & & & & & & & & 1 & & & & & & 1 \\
\hline
\end{tabular}

Note:

*. Correlation is significant at the 0.05 level (2-tailed)

**. Correlation is significant at the 0.01 level (2-tailed)

Table 6: Frequency of pairwise correlations from the SRM survey instrument 


\begin{tabular}{|l|c|l|l|l|}
\hline \multirow{2}{*}{$\begin{array}{c}\text { SRM } \\
\text { Survey } \\
\text { Question }\end{array}$} & $\begin{array}{c}\text { Frequency } \\
\text { Rank }\end{array}$ & $\begin{array}{c}\text { First } \\
\text { Factor }\end{array}$ & $\begin{array}{c}\text { Second } \\
\text { Factor }\end{array}$ & $\begin{array}{c}\text { Third } \\
\text { Factor }\end{array}$ \\
\hline FACE2 & 1 & SS2 & & \\
\hline FACE4 & 1 & SS2 & & \\
\hline FACE6 & 1 & SS2 & & \\
\hline ECAT3 & 1 & SS2 & EVS2 & \\
\hline ECAT4 & 1 & SS2 & EVS2 & \\
\hline SRM6 & 1 & SS2 & EVS1 & \\
\hline MARK3 & 2 & LGOM1 & & \\
\hline EDI3 & 2 & LGOM1 & & \\
\hline OTHERS1 & 2 & LGOM1 & EVS1 & \\
\hline DEMO10 & 3 & ES2 & & \\
\hline EDI1 & 3 & ES2 & SS2 & \\
\hline MARK2 & 3 & ES3 & & \\
\hline SRM4 & 3 & ES3 & & \\
\hline ECAT1 & 3 & EVS2 & & \\
\hline ECAT2 & 3 & EVS2 & & \\
\hline EAUCT1 & 4 & ES4 & ES2 & SS2 \\
\hline EDI2 & 4 & EVS1 & ES2 & LGOM1 \\
\hline DEMO8 & 4 & SS1 & & \\
\hline
\end{tabular}

Table 7: Mapping of SRM-SOM to coded correlations 